\title{
GROWTH OF MEASLES VIRUS IN A MOUSE DERIVED ESTABLISHED CELL LINE L CELLS
}

\author{
SEIYA KOHNO, MASAYOSHI KOHASE AND MASARU SUGANUMA \\ Department of Measles Virus, National Institute of Health, \\ Murayama-Branch, Nakato, Murayama-Machi, Tokyo 190-12, Japan
}

(Received : July 31st, 1968)

\begin{abstract}
SUMMARY : Measles virus was found to grow in L cells, without producing cytopathic effects. The growth curve experiments revealed two phases of infection, viz., the early logarithmic multiplication and the later persistent state of infection. Studies on viral penetration and uncoating (or disintegration) demonstrated the relatively low efficiencies in both reactions. Release of the progeny viruses was also suppressed. They were found mostly in the extreme neighborhood of the cell membrane.

Most of the cells at the later phase of infection were susceptible to measles virus, when tested after cell-cloning. They were carrying no virus or virusrelated antigens (as tested by subculture with mixed Vero cells, or by fluorescent antibody staining and hemadsorption).

These findings, altogether, indicate a suppression in spreading of the viruses in the culture.

When the cultures of the later phase of infection were treated with $\mathrm{PH} 3.0$ for 5 minutes, the total cell-associated infectivity dropped drastically. But subsequently, without a lag, a prompt recovery of infectivity was observed.
\end{abstract}

\section{INTRODUCTION}

Measles virus is known to replicate in a variety of mammalian cells, e. g., AV-3, HeLa cells (Thomison, 1962), Chang liver, conjunctiva, FL cells (Toyoshima et al., 1959, 1960), KB cells (Kohn and Yassy, 1962), Vero cells (Shishido et al., 1967) and MEC-La strain of mouse embryo cells (Parfanovich et al., 1966).

Although most of the cells listed above are capable of supporting complete cycles of the viral multiplication, there have been reports on the incidences of an incomplete growth and/or an establishment of a persistent state of infection in HeLa cells (Rustigian, 1962) and Lu109 cells (Norrby, 1965).

In this communication, growth of measles virus in the monolayer of $\mathrm{L}$ cells is reported. After an initial rapid multiplication of the virus, the total infectivity decreased slowly until the cells became persistently infected. No evidence of cytopathic effect was obtained throughout this process. Detailed observations on the virus-cell interactions are reported.

\section{MATERIALS AND METHODS}

Cells and media: Earle's L cells, of which passage history is unknown, were obtained from the Department of Enteroviruses of this Institute. Vero cells, an establi-

河野 晴也・小長谷 昌功・菅沼 優（国立予防衛生研究所麻しんウイルス部） 
shed cell line of African green monkey kidney (Yasumura and Kawakita, 1963) were used at the passage level of 240-260. HeLa cells were used only in the preparation of measles virus seed pools. The culture medium for these cells was Earle's balanced salt solution containing $0.5 \%$ lactoalbumin hydrolyzate, $0.1 \%$ yeast extract, 100 units/ $\mathrm{ml}$ of penicillin, $100 \mu \mathrm{g} / \mathrm{ml}$ of streptomycin and unheated calf serum at concentrations of $10 \%$ and $2 \%$ in the growth and maintenance media, respectively.

Visuses: A plaque purified Toyoshima strain of measles virus, TYCSA, was used. This strain had a passage history of 52 subculturings in FL cells and 5 subculturings in Vero cells. After three plaque purifications in Vero cells, the virus received additional 5 passages through Vero cells. Seed virus stocks were prepared in HeLa cells, incubating infected cultures at $30 \mathrm{C}$. The incubation at this low temperature gave rise to a high yield of measles virus in 9-10 days (Shishido, unpublished). When the culture showed maximal cytopathic effects, a frozen-thawed (3 times) homogenate was clarified by a low speed centrifugation, and stored in small $(2 \mathrm{ml})$ vials at $-80 \mathrm{C}$.

Plaque titration: Infectivity of measles virus was titrated by a plaque method. Monolayers of Vero cells in $50 \mathrm{ml}\left(6 \times 3 \mathrm{~cm}^{2}\right)$ plaque bottles were inoculated with 0.5 $\mathrm{ml}$ of serial 10-fold dilutions of a virus suspension. After adsorption for $1 \mathrm{hr}$ at $37 \mathrm{C}$, inocula were removed and $5 \mathrm{ml}$ per bottle of agar overlay medium (maintenance medium containing $1.0 \%$ Noble's agar) was added. After 5 days, incubation at $37 \mathrm{C}$, cells were stained with neutral red (final concentration : $1: 30,000$ ). Round, uniformly sized (4-6 $\mathrm{mm}$ in diameter) plaques were usually obtained in $10-20 \mathrm{hr}$ at room temperature after the staining.

Infective center assay: Titration for infective centers (IC) was performed followingly. Infected L cells were first dispersed by 30 seconds' contact with $0.05 \%$ trypsin in Dulbecco's phosphate buffered saline (PBS). They were washed once with growth medium, and suspended in maintenance medium of a suitable volume. Viable cell concentration was determined by counting trypan-blue $(0.167 \%)$ rejecting cells on a hemocytometer. One-half $\mathrm{ml}$ of the cell suspensions, diluted serially by 10 -fold with maintenance medium, was mixed with $5 \mathrm{ml}$ of a freshly prepared Vero cell suspension (about $10^{6}$ cells $/ \mathrm{ml}$ ) in a $50 \mathrm{ml}$ plaque bottle, containing 16 neutralizing units per $\mathrm{ml}$ of guinea pig anti-measles antibody. After an incubation overnight at $37 \mathrm{C}$, when the mixtures of cells had sheeted completely, media were removed and $5 \mathrm{ml}$ per bottle of agar overlay medium (the same as that used in plaque titration) was added. Staining and counting of plaques (each corresponding to an IC) were done as described in the titration of plaque forming units (PFU).

Measurement of measles virus penetration: The penetrating fraction of cell-associated measles virus was titrated as acid-resistant IC, of which detailed procedures had been given previously by Suganuma (1967).

In short, measles virus was adsorbed onto suspended $\mathrm{L}$ or Vero cells at $4 \mathrm{C}$ for 1 $\mathrm{hr}$ at a multiplicity of infection (moi) around 0.01-0.001 PFU/cell to avoid multible infections of the virus in a single cell. To initiate the viral penetration, temperature of the infected cell suspension was quickly raised up to $37 \mathrm{C}$. At appropriate time intervals, penetration was terminated by mixing 1 volume of the suspension with 9 volumes of glycin- $\mathrm{HCl}$ buffer saline (GHS) of the following ingredients : $0.14 \mathrm{M} \mathrm{NaCl}$, $8 \mathrm{mM}$ glycin, $0.001 \mathrm{~N} \mathrm{HCl}, 1.2 \mathrm{mg} / \mathrm{ml}$ of bovine serum albumin (Armour's fraction $\mathrm{V})$. Resultant $\mathrm{pH}$ of the final mixture was 3.0 where infectivity of measles virus dropped to below $10^{-4}$ within 30 seconds. There was obtained no inhibitory effect on 
the viability of pre-formed IC by this acid treatment. After 5 minutes at room temperature, the $\mathrm{pH}$ was brought back to 7.0 by addition of a pre-determined amount of $\mathrm{M} / 15 \mathrm{Na}_{2} \mathrm{HPO}_{4}$, and IC were assayed on monolayers of Vero cells. The addition of neutralizing antibody to avoid secondary infection was not necessary, because the appearance of progeny viruses was not detectable at the earliest $10 \mathrm{hr}$ after infection, and until that time IC had attached on the glass wall completely. Subsequent procedures were the same as described in the measurement of IC.

Interferon assay: VSV was employed as a challenge virus, proceduces for assay of interferon potency were described elsewhere (Kohno, Kohase and Suganuma, 1968a).

Guinea pig antiserum: Anti-measles virus serum was prepared in guinea pigs by repeated subcutaneous inoculations of an inactivated measles virus suspension using aluminium phosphate as an adjuvant. Neutralizing antibody titer of the pooled sera was $1: 2560$ against 100 tissue culture infective dose $\left(\right.$ Vero-TCID $\left.{ }_{50}\right)$ of the virus.

Fluorescent antibody staining: Fluorescin isothiocyanate labeled monkey antimeasles antibody was a gift of Dr. Kobune of this laboratory. Its neutralizing antibody titer was $1: 2560$, and the staining titer was $1: 32$ and $\mathrm{F} / \mathrm{P}$ was 2.8. Monolayers of test cells grown on coverslips were washed with PBS, fixed with acetone at $-20 \mathrm{C}$ fo 10 minutes and stained with the labeled antibody at $4 \mathrm{C}$ overnight. Specimens were examined under a Nikon ultraviolet microscope.

Hemadsorption test: Before formation of a confluent monosheet, cells in $50 \mathrm{ml}$ plaque bottles were washed with PBS and adsorbed with $1.0 \mathrm{ml}$ per bottle of a $1 \%$ suspension of African green monkey's red blood cells. Hemadsorption was examined under a conventional microscope after an incubation at $4 \mathrm{C}$ for $1 \mathrm{hr}$ and washing with cold PBS.

Antimetabolites: Cycloheximide was a product of Upjohn Company, Kalamazoo, Michigan, U.S. A. (Lot ST772-C4). Actinomycin D was obtained from Mann Research Laboratories, and Mitomycin $\mathrm{C}$ was purchased from Kyowa Hakko Company, Tokyo.

\section{RESULTS}

\section{Growth Curves}

Monolayers of $\mathrm{L}$ cells in test tubes $\left(3 \times 10^{5}\right.$ ceils/tube) were infected with measles virus at a moi of nearly $200 \mathrm{PFU} /$ cell. After $2 \mathrm{hr}$ of adsorption at $37 \mathrm{C}$, the cultures were treated with GHS for 5 minutes, washed once and fed with $1 \mathrm{ml}$ per tube of maintenance medium. Development of infectivity in medium and frozen-thawed total homogenate of the culture is plotted in Fig. 1.

As shown in the figure, the virus multiplied in a logarithmic fashion within $24 \mathrm{hr}$ post infection. After a plateau the infectivity decreased rapidly until $100 \mathrm{hrs}$ post infection. No cytopathic change was evidenced throughout the observation period. The infectivity in the medium became detectable several hr after the commencement of the logarithic growth and reached a maximum of a considerably low titer (approximately $0.1 \%$ of the peak of the total virus).

The initial logarithmic multiplication and subsequent plateau will be designated as the early phase of infection.

In a separate experiment, IC and cell associated virus were examined in an extended time period. Infection and sampling of $\mathrm{L}$ cells were performed in a similar man- 


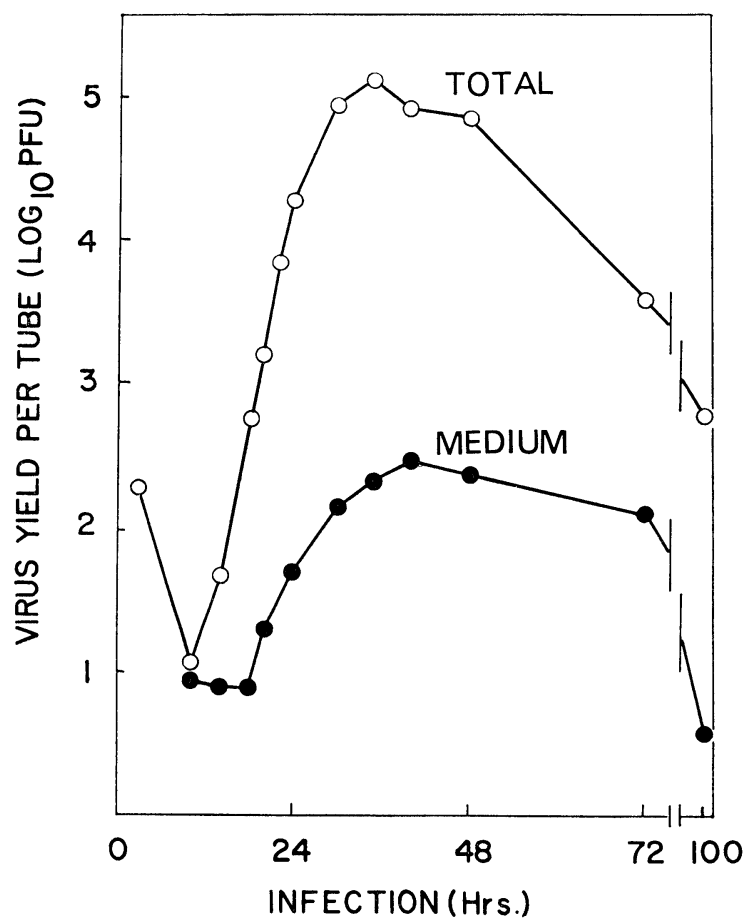

Fig. 1. Growth of measles virus in $\mathrm{L}$ cells (short term).

Open circles: Frozen thawed homogenate of the culture.

Closed circles: Medium after clarification by low speed centrifugation.

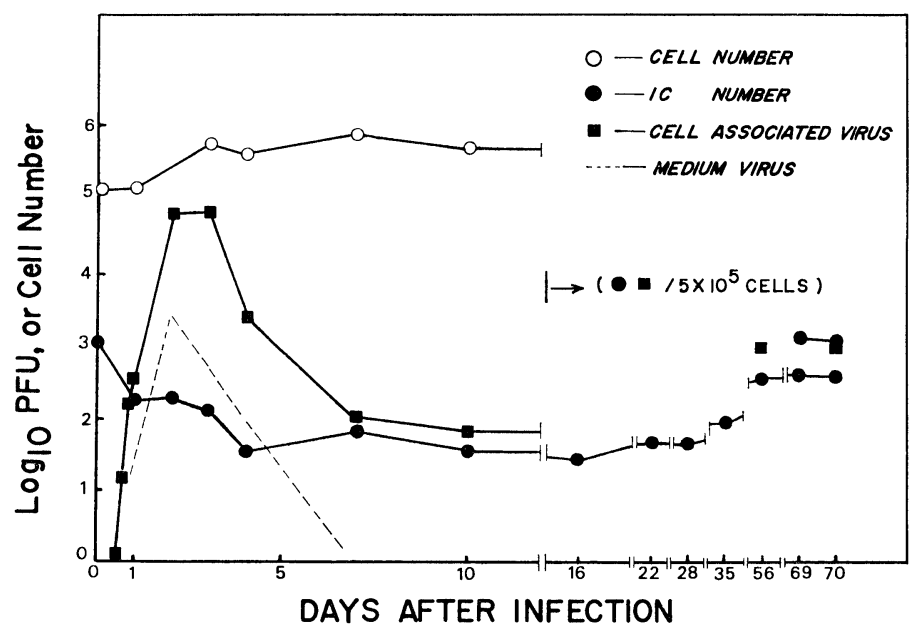

Fig. 2. Growth and persistence of measles virus in $\mathrm{L}$ cells. 
ner described in the preceeding experiment, except for the use of $50 \mathrm{ml}$ plaque bottles instead of test tubes, and a lower moi of around $3 \mathrm{PFU} /$ cell. Results are summarized in Fig. 2, together with the cell number per bottle until 10 days later. The infected cultures were passed first on the 11th day, and subsequently after every 7-8 days.

As seen in the figure, the cultures became a "persistently infected" state on the 7 th day post infection and thereafter. This period will be designated as the later phase of infection. Cell sheets in the later phase looked healthy, grew as fast as uninfected controls in a growth medium without an addition of neutralizing antibody.

In another experiment, where a lower moi of $0.01 \mathrm{PFU} /$ cell was employed, the infectivity plateau lasted for more than $100 \mathrm{hr}$ (data are not shown). The eclipse period and the initial velocity of the logarithmic growth appeared to be little affected by the difference in moi.

The concentration of IC in the early phase of infection were unexpectedly low. In the later phase, the number of IC was found to increase gradually to the level of $10^{3}$ IC per $5 \times 10^{5}$ cells. The hemadsorbing and fluorescent antibody stained cells were very few (about $1 \%$ of the total) in the early phase, and disappeared completely in the later phase.

\section{Penetration and Uncoating (or Disintegration)}

To investigate the early events of measles viral infection in $\mathrm{L}$ cells, the penetration and uncoating (or disintegration) processes were studied.

A typical result on the time course of the penetration of measles virus in suspended $\mathrm{L}$ cells is shown in Fig. 3. In this experiment, a moi of $0.01 \mathrm{PFU} /$ cell was chosen so that one IC would approximately correspond to one virus particle which penetrated. The experimental procedures were given in Materials and Methods. The penetration, as expressed by the increment of acid resistent IC, reached its maximum usually at 30-40 minutes. The time required for $50 \%$ of adsorbed virus particles to penetrate was around 10 minutes.

Fig. 4 is the result of an experiment on time-dependent decrease of infectivity in $\mathrm{L}$ cells infected with measles virus. Monolayers of $\mathrm{L}$ cells in test tubes were adsorbed with measles virus at a moi of $100 \mathrm{PFU} /$ cell for 40 minutes at $37 \mathrm{C}$. The viral infectivity that had not penetrated was removed by the treatment with GHS (Materials and Methods). Each tube received $1 \mathrm{ml}$ of maintenance medium, and then at suitable time intervals two tubes were frozen-thawed four times. The homogenates were pooled and assayed for PFU.

The decrease of infectivity was found very slow in L cells as compared with that in Vero cells. In the latter, this method was not applicable because of a very rapid fall of infectivity within 10 minutes after the penetration.

\section{Clone Purification of $L$ Cells}

To investigate whether the $\mathrm{L}$ cells employed in these experiments were homogeneous in respect to their response to measles virus infection, clone purifications were performed according to the methods described elsewhere (Kohno, Kohase and Suganuma, 1968b). Five clonal cells arbitrarily chosen were capable of supporting the early rapid multiplication of the virus equally well. This seems to ensure the hemogeneity in population of host cells as far as the tested criterion is concerned.

A number of trials to obtain a clone consisting only of IC from the infected cultures 


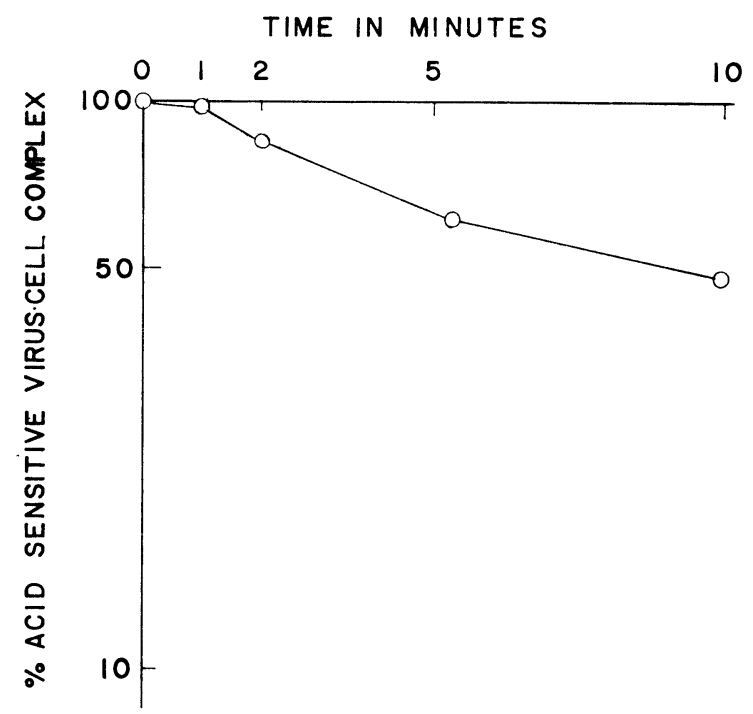

Fig. 3. Time course of the penetration of measles virus in L cells.

The percentages were calculated on the basis of IC number at 40 minutes $(0 \%)$.

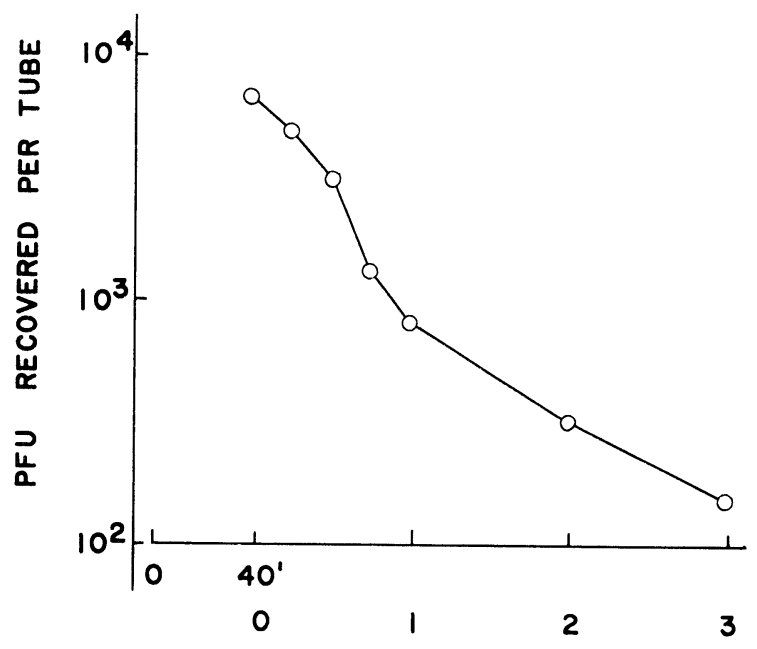

Hours After Infection

Fig. 4. Disappearance of infectivity of measles virus after the penetration in $\mathrm{L}$ cells (uncoating).

in the later phase were unsuccessful, indicating that the culture contained chiefly normal cells. No incidence of recovery of infective virus was encountered in the mixed culture of the isolated clones in the later phase and Vero cells. Furthermore, these clones from persistently infected cultures were negative in fluorescent antibody staining test, and were equally susceptible to the re-challenge with measles virus. 


\section{Inactivations of Cell-Associated Measles Virus Infectivity by GHS and Neutralizing Antibody}

Addition of an anti-measles virus antibody or an acidification by mixing with GHS to $\mathrm{pH} 3.0$ for 5 minutes resulted in an inactivation of a part of cell associated measles viral infectivity.

Table 1. Inactivations of cell-associated measles virus infectivity by low $\mathrm{pH}$ and neutralizing antibody

\begin{tabular}{|c|c|c|c|c|c|}
\hline \multirow{2}{*}{$\begin{array}{l}\text { Days post } \\
\text { infection }\end{array}$} & \multicolumn{5}{|c|}{$\mathrm{PFU}$ recovered (per ml) } \\
\hline & $\begin{array}{c}\text { Total virus } \\
(\text { cell }+ \text { medium })\end{array}$ & Medium virus & $\begin{array}{l}\text { After } \\
\text { with }\end{array}$ & $\begin{array}{l}\text { treatment } \\
\text { GHS* }\end{array}$ & $\begin{array}{l}\text { After treatment } \\
\text { with antiserum }\end{array}$ \\
\hline 1 & $1.6 \times 10^{2}$ & $\begin{array}{r}2.5 \times 10 \\
(15.6) * *\end{array}$ & 1.2 & $(0.75)$ & $\begin{array}{ll}2.8 & \\
& (1.75)\end{array}$ \\
\hline 2 & $6.4 \times 10^{4}$ & $\begin{array}{r}3.5 \times 10^{3} \\
(5.5)\end{array}$ & 4.0 & $(0.0063)$ & $\begin{array}{l}1.9 \times 10^{2} \\
(0.28)\end{array}$ \\
\hline 3 & $6.8 \times 10^{4}$ & $\begin{array}{r}6.5 \times 10^{2} \\
(0.96)\end{array}$ & 4.0 & $(0.0059)$ & $\begin{array}{l}2.9 \times 10 \\
(0.043)\end{array}$ \\
\hline
\end{tabular}

* Glycin-HCl buffer saline (materials and methods).

** Per cent to total virus.

Fresh L cell monolayers in test tubes were infected with measles virus at a moi of $3 \mathrm{PFU} /$ cell at $37 \mathrm{C}$ for $1 \mathrm{hr}$, treated with GHS for 5 minutes to remove unadsorbed viruses, washed once and incubated at $37 \mathrm{C}$ in $1 \mathrm{ml}$ per tube of maintenance medium. After 1, 2, and 3 days, PFU contents of the following materials were assayed: 1) frozen-thawed homogenate of cells and media of two tubes (total infectivity), 2) media of two tubes after clarification by a low speed centrifugation (media infectivity), 3) frozen-thawed homogenate of cells of two tubes after treatment with GHS (GHS-resistant fraction), and 4) frozen-thawed homogenate of cells of two tubes after treatment with antiserum (antibody-resistant fraction). The detailed procedures of the antibody treatment was as follows. The cells of two tubes were incubated with $1 \mathrm{ml}$ per tube of maintenance medium containing 165 neutralizing units $/ \mathrm{ml}$ of antibody at $35 \mathrm{C}$ for 10 minutes. They were washed twice with $5 \mathrm{ml}$ per tube of maintenance medium, and then frozen and thawed three times.

As shown in Table, 1 the percentage of medium virus to the total decreased from 16 to $1 \%$ in 3 days of infection, indicating an intracellular accumulation of progeny virus during this period. Much of the infectivity was inactivated by GHS and antiserum treatment suggesting that most of the progeny viruses in $\mathrm{L}$ cells were located within a distance from the cell membrane where GHS and antibody could give influence in 5 and 10 minutes, respectively.

\section{Recovery of Measles Viral Infectivity in the Cultures of the Later Phase of Infection after the Low pH Treatment}

As observed in the preceeding section, the acidification of $\mathrm{L}$ cells infected with measles virus resulted in an inactivation of the majority of the progeny viruses. However, as soon as the $\mathrm{pH}$ was brought back to neutral, the PFU content of the $\mathrm{L}$ cells began to be restored without a lag. 


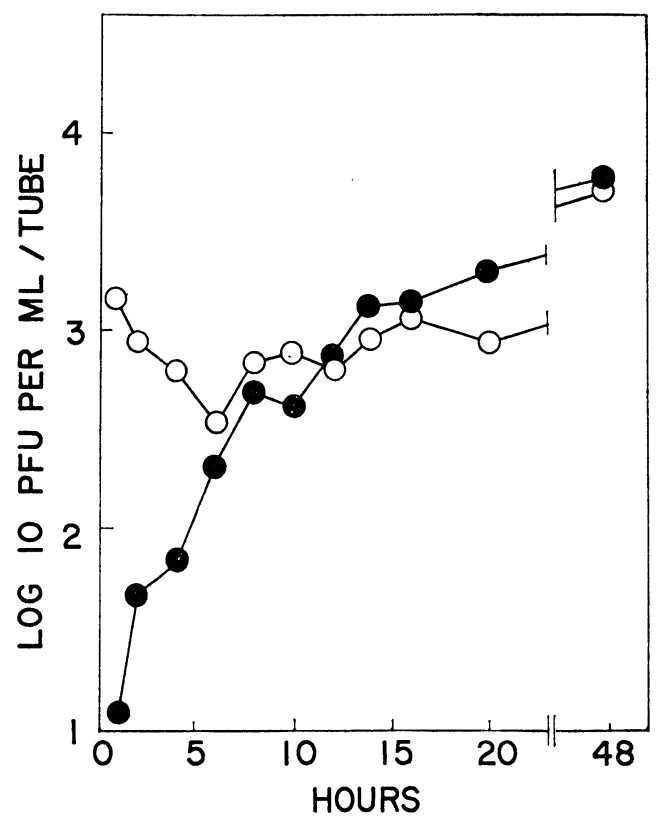

Fig. 5. Recovery of measles viral infectivity in infected cultures after the low $\mathrm{pH}$ treatment.

Open circles: Non-treated control.

Closed circles: Treated wsth $\mathrm{pH} 3.0$ buffer for 5 minutes.

A typical result of the time course of this recovery is shown in Fig. 5. L cells carrying measles virus for 56 days were dispersed by trypsinization, washed once and diluted with growth medium to give a cell concentration of $4 \times 10^{5}$ cells $/ \mathrm{ml}$. Thirty $\mathrm{ml}$ aliquots of the suspension was treated with GHS for 5 minutes, washed once with growth medium and suspended in the original volume of growth medium. For control, $30 \mathrm{ml}$ aliquots were treated identically except for the GHS treatment. One $\mathrm{ml}$ aliquot of both suspensions, control and experimental, was delivered into each test tube and incubated at $37 \mathrm{C}$. At appropriate time intervals, two tubes from each group were frozen away at $-80 \mathrm{C}$ until the PFU titration after disrupting cells by freezing and thawing three times.

As seen in the figure, the PFU content of acid-treated cells increased to the level of control within 7-8 hr. During this period, no significant alteration in the level of IC was evidenced.

This phenomenon will also be explained by assuming an temporal dissociation of viral components by the low $\mathrm{pH}$ and a commencement of reconstruction of virus particles when the $\mathrm{pH}$ was brought back to neutral.

Therefore, to test the dependence of this process on the viral synthetic reactions, some antimetabolites, i. e., cycloheximide, actinomycin $\mathrm{D}$ and mitomycin $\mathrm{C}$ at various concentrations were examined for their effects on this process. Among them, only cycloheximide was found inhibitory.

L cells which had been maintained for 84 days after infection were used. Test tubes containing GHS treated cells were prepared as described in the preceeding 


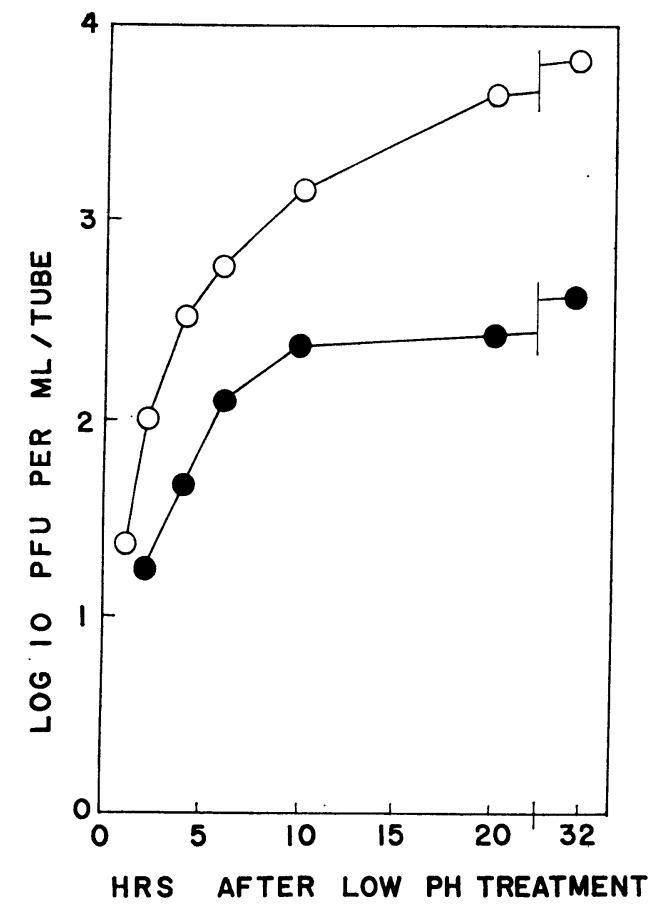

Fig. 6. Inhibition of the recovery process by cycloheximide.

Open circles : Control recovery after the low $\mathrm{pH}$ treatment.

Closed circles : Recovery in the presence of $10 \mu \mathrm{g} / \mathrm{ml}$ of cycloheximide.

experiment.

Cycloheximide was added at a final concentration of $10 \mu \mathrm{g} / \mathrm{ml}$ exactly one hr after the low $\mathrm{pH}$ treatment and left on thereafter. Cells which received PBS in place of the antibiotic served as control. Subsequent procedures were the same as given in the preceeding experiment.

Results are shown in Fig. 6. As seen in the figure, the suppression of the recovery process was not $100 \%$ even at the maximum concentration of $10 \mu \mathrm{g} / \mathrm{ml}$ employed in this experiment. An apparent cytotoxic effect was observed beyond this concentration of the drug. The magnitude of inhibition (about $95 \%$ ) was not altered at the effective rninimum concentration of $0.5 \mu \mathrm{g} / \mathrm{ml}$.

\section{Discussion}

In this paper measles virus was shown to replicate in $\mathrm{L}$ cells. After a rapid multiplication (early phase), the virus was found to persist in the culture at a low level (later phase). The virus did not produce cytopathic effect throughout these phases of infection.

Clonal purification of normal $L$ cells employed in this study revealed that they were homogeneous in respect to their capacities to support the early phase of measles viral multiplication. It was also elucidated by cell cloning that the cultures in the later 
phase of infection consisted mostly of normal cells susceptible to the virus. This is in good agreenment with our result in the IC assay, which indicates that at least several hundred clone must be prepared to encounter the one carrying the virus. It was not ruled out, however, that the IC was not viable enough to form a recognizable clone in a diluted cell suspension during the cloning process.

Experiments to investigate the early interactions of measles virus and $\mathrm{L}$ cells have shown that the viral transmission from cell to cell is restricted by the low efficiencies in viral release (Fig. 1), (Table 1), and penetration (Fig. 3). The penetration process was found almost 5 times slower in L cells than in Vero cells (Suganuma, 1967).

Furthermore, incidences of the establishment of "productive" infection (formation of IC) seemed to be very few even at the relatively high moi employed (Fig. 2). This probably implies either that the efficiency in the adsorption/penetration step may be low, or that most of the cell-virus interactions may be abortive in $\mathrm{L}$ cells.

In the experiment illustrated in Fig. 1, each medium sample was assayed for the interfering activity with VSV plaque formation. Only the medium of the culture at $72 \mathrm{hr}$ post infection exhibited an interfering activity corresponding to 32 units $/ 2 \mathrm{ml}$ of interferon. The role of the interferon-like activity of the medium in this cell-virus equilibrium is not yet clear at present.

There have been reported on a carrier state of myxovirus infection being accompanied by and propably resulting from an incomplete viral growth (Rustigian, 1962, Miyamoto, Hinuma and Ishida, 1965). In this measles virus-L cell system, our trials to demonstrate directly virus-related antigens in the persistently infected cells by fluorescent antibody staining or hemadsorption were unsuccessful.

Assuming that GHS and antiserum inactivate the cell associated infectivities depending upon their accessible ranges from the cell membrane, an estimation of intra-cellular distribution of progeny virus was made. The results presented in Table 1 elucidated the time-dependent accumulation of the virus in a region very close to the membrane. Indeed, almost $99.994 \%$ of the total cell associated virus was found sensitive to the acid treatment on the 3rd day of infection. Although a possibility cannot be excluded that a small amount of antibody attached to the cell surface resisted washing and inactivated intra-cellular virus when cells were homogenized, the antiserum also seemed to inactivate most of the cell-associated infectivity. This finding is in good accordance with the present knowledge on the mode of the growth of myxoviruses that they maturate at the cell membrane and are released into medium by budding (Duc-Nguyen, Rose and Morgan, 1966). The treatment with low pH was always more efficient in inactivating cell-associated infectivity than the neutralization by antibody. This implies either the GHS may influence deeper than the antibody of high molecular weight, or the intra-cellular virus may be more rapidly inactivated by the low $\mathrm{PH}$ environment than the neutralization by antibody.

The immediate commencement of the recovery of infectivity after the inactivation by low $\mathrm{pH}$ (Fig. 5) and inhibition of this process by cycloheximide (Fig. 6) implies that the pathway of synthesis of viral protein components are still operative in the cells of the later phase of infection. If this was the case, the recovery persisting at a diminished rate in the presence of $10 \mu \mathrm{g} / \mathrm{ml}$ of cycloheximide may represent preformed viral protein component ready to be incorporated into virions endowing them with infectivity.

It remained unanswered whether an IC in the lather phase of infection can multiply 
with the virus, or disintegrates after having released progeny viruses. The IC content of the infected cultures have decreased to an untetectable level on the 350th day of infection. Yet, it is still uncertain whether the cultures are "cured" or not.

\section{REFERENCES}

Doc-Nguyen, E., Rose, H. M. ANd MoRgan, C. (1966) : An electron microscopic study of changes at the surface of influenza-infected cells as revealed by ferritin conjugated antibodies. Virol., 28, 404-412.

KoHN, A. AND YAssky, D. (1962) : Growth of measles virus in KB cells. Virol., 17, 157163.

Kohno, S., Kohase, M. And Suganuma, M. (1968 a): Inhibition of interferon synthesis by chloroquire diphosphate. Japan. J. Med. Sci. Biol. 21, 239-248.

Kohno, S., Kohase, M. And Suganuma, M. (1968 b) : Establishment of a clone of BHK21 cells favourable to rubella hemagglutinin production. Japan. J. Med. Sci. Biol. 21, 289-293.

Miyamoto, T., Hinuma, Y. AND IshidA, N. (1965): Intracellular transfer of hemadsorption type 2 virus antigen during persistent infection of HeLa cell cultures. Virol., 27, 28-36.

NoRRBY, E. (1965): Characteristics of the progeny derived from multiplication of Sendai virus in a measles virus carrier cell line. Arch. ges. Virusforsch, 17, 436-442.

Parfanovich, M. I., Sokolov, N. N., Zmieva, R. G., Gavrilov, V. I., Fadeyeva, L. L. AND Mishin, L. N. (1966): Peculiarities of measles virus multiplication in roller-suspension cultures on passaging by mixtures of infected and uninfected cells. Acta Virol., 10, 322-327.

Rustigian, R. (1962): A carrier state in HeLa cells with measles virus (Edmonston strain) apparently associated with noninfectious virus. Virol., 16, 101-104.

Shishido, A., Yamanouchi, K., Hikita, M., Sato, T., Fukuda, A. and Kobune, F. (1967): Development of a cell culture system susceptible to measles, canine distemper, and rinderpest viruses. Arch. ges. Virusforsch., 22, 364-380.

SugAnumA, M. (1967): Penetration of measles virus in vero cells, assay procedure and severl basic properties. Virus (text in Japanese, with a summary in English), 17, 44-54.

Thomison, J. B. (1962): Evolution of measles giant cells in tissue culture, analysis by time lapse microcinematography. Lab. Investigation, 11, 211-219.

Toyoshima, K., Hata, S., Takahashi, M., Miki, T., Kunita, N. and OKuno, Y. (1959) : Virological studies on meales virus. II. Growth of Toyoshima strain in four established cell lines. Biken's J., 2, 313-320.

Toyoshima, K., Hata, S., Takahashi, M., Miki, T. And Okuno, Y. (1960) : Virological studies on measles virus. III. Morphological changes and virus growth in FL cultures. Biken's J., 3, 241-248.

YasumuRA, Y. AND Kawakita, Y. (1963): Studies on SV40 virus in tissue cultures. Nihon Rinsho, 21, 1201-1215. (text in Japanese) 